\title{
PELAYANAN DAN PENDAMPINGAN BANTUAN HUKUM GRATIS UNTUK MASYARAKAT MISKIN DI PROVINSI LAMPUNG
}

\author{
Masayu Robianti \\ Universitas Sang Bumi Ruwa Jurai \\ Fakultas Hukum Program Studi Ilmu Hukum \\ 79masayurobianti@gmail.com
}

\begin{abstract}
Abstrak
Bantuan hukum diberikan secara cuma-cuma kepada orang yang atau sekelompok orang miskin. Pemberi bantuan hukum adalah lembaga bantuan hukum atau organisasi kemasyarakatan yang memberi layanan bantuan hukum berdasarkan Undang-Undang No. 16 Tahun 2011 tentang Bantuan Hukum. Penyelengara bantuan hukum adalah Kementrian HAM RI. Masyarakat miskin berhak mendapatkan bantuan hukum hingga masalah hukumnya selesai dan atau perkaranya telah mempunyai kekuatan hukum tetap, selama penerima bantuan hukum yang bersangkutan tidak mencabut kuasa. Pendekatan masalah yang digunakan untuk penelitian ini adalah pendekatan secara yuridis normatif dan secara yuridis empiris. Analisis data dengan analisis yuridis kualitatif. Kesimpulan Pelayanan bantuan hukum secara cuma-cuma atau gratis dalam Undang-Undang Nomor 16 Tahun 2011 tentang Bantuan Hukum tertuang dalam Pasal 1 ayat 2 dan Pasal ayat 1 sampai dengan ayat 3. Ruang lingkup Bantuan Hukun juga memuat penerima bantuan hukum dan hak dasar penerima bantuan hukum tercantum dalam Pasal 5 ayat 1 dan ayat 2 Undang-Undang Nomor 16 Tahun 2011. Persyaratan dan mekanisme pelaksanaannya pelayanan bantuan hukum secara cuma-cuma atau gratis dalam Undang-Undang Nomor 16 Tahun 2011 di atur dalam Bab VI Syarat dan Tata Cara Pemberian Bantuan Hukum yang di jelaskan dalam Pasal 14 ayat 1 dan ayat 2 , Pasal 15 ayat 1 sampai dengan ayat 5 .
\end{abstract}

Kata Kunci: Pelayanan, Pendampingan, Bantuan, Hukum, Masyarakat

\begin{abstract}
Legal aid is provided free of charge to a person or group of poor people. Legal aid providers are legal aid institutions or social organizations that provide legal aid services based on Law No. 16 of 2011 concerning Legal Aid. The organizer of legal aid is the Indonesian Ministry of Human Rights. The poor are entitled to legal aid until their legal problems are resolved and or the case has permanent legal force, as long as the recipient of legal aid concerned does not withdraw their power of attorney. The approach to the problem used for this research is a normative juridical approach and a juridical empirical approach. Data analysis using qualitative juridical analysis. Conclusion Free or free legal aid services in Law Number 16 of 2011 concerning Legal Aid are contained in Article 1 paragraph 2 and Article paragraph 1 to paragraph 3.The scope of Legal Aid also contains legal aid recipients and the basic rights of aid recipients The law is contained in Article 5 paragraph 1 and paragraph 2 of Law Number 16 Year 2011. The requirements and mechanisms for implementing free or free legal aid services in Law Number 16 Year 2011 are set out in Chapter VI Terms and Procedures for Providing Assistance The law described in Article 14 paragraph 1 and paragraph 2, Article 15 paragraph 1 to paragraph 5.
\end{abstract}

Keywords: Service, Assistance, Assistance, Law, Society

\section{PENDAHULUAN}

Sistem hukum Indonesia Undang-Undang Dasar 1945 menjamin adanya persamaan dihadapan hukum (equatity before the law), sehingga dalam Pasal 27 ayat 1 Undang--Undang Dasar 1945 disebutkan, setiap warga Negara bersamaan kedudukannya dalam hukum dan pemerintahan itu dengar tidak ada kecualinya. Salah satu upaya untuk mewujudkan keadilan atau kesamaan kedudukan dalam hukum yaitu dengan adanya bantuan hukum bagi setiap warga 
negara yang terlibat dalam kasus hukum, akan tetapi pada kenyataannya baltual hukum hanya mampu dirasakan oleh orang yang mampu saja.

Masalah bantuan hukum tentu bagi kalangan yang memiliki kemampuan secara ekonomi dapat menunjuk advokat jika dibutuhkan untuk membela kepentingannya. Sedangkan bagi kalangan miskin tidak memiliki kemampuan secara ekonomi tidak dapat menunjuk advokat sebagaimana yang dilakukan oleh kelompok yang memiliki kemampuan secara ekonomi Menjamin hak masyarakat mendapatkan bartuan hukum khususnya bagi masyaralat miskin. Negara memiliki kewajiban untuk menyediakannya. Hal ini sebagai konsekunesi logis dan pengakuan negara yan mengatakan "Segala warga negara bersamaan kedudukannya di dalam hukum dan pemerintahan dan wajrb menjunjung hukum dan pemerintahan itu dengan tidak ada kecualinya (Pasa.1 27 ayat 1 UUD 1945) ". Pasal 34 ayat 11) UUD 1945 menegaskan Fakir miskin dan anak-anak yang telantar dipelihara oleh negara. Hal ini secara ekstensif dapat ditafsirkan bahwa negara bertanggung jawab memberikan perlindungan dan pengakuan terhadap hak hak fakir miskin (Winatla, 2007)

Undang-Undarg Nomor 12 Talun 2005 tentang Kovenan Internasional Hak-hak Sipil dan Palitik (Lembdran Negara Nomor 119 Tahun 2005, Tambahan Lembaran Negara Nomor 45581 mengakui hak atas bantuan hukum dan hak atas Advokat dan memerintahkan negara untuk menyediakan Advokat yang memberikan bantuan hukum secara efektif untuk masyarakat miskin. Sampai saat ini hak masyarakat untuk mendapat bantuan hukum belum sepenuhnya lerpenuhi.

\section{METODE PENELITIAN}

Metode penelitian yang digunakan dalam penulisan ini bersifat yuridis normatif, dan pendekatan empiris. Data yang digunakan adalah data sekunder dan data primer. Analisis data menggunakan analisis yuridis kualitatif.

\section{HASIL DAN PEMBAHASAN}

\section{Pelayanan dan Bantuan Hukum Secara Cuma-Cuma Atau Gratis dalam Undang Undang Nomor 16 Tahun 2011}

Konstitusi menjamin hak setiap warga negara mendapat perlakuan yang sama di muka hukum, termasuk hak untuk mengakses keadilan melalui pemberian bantuan hukum. Orang kaya dan mempunyai kekuasaan, dengan mudah mengakses dan mendapatkan "keadilan", melalui tangan-tangan advokat yang disewanya. Tidak demikian halnya dengan kelompok masyarakat miskin, mereka tidak mampunyai kemampuan untuk memahami hukum dan tidak mampu untuk membayar advokat, hal demikian menyebabkan tidak ada perlakuan yang sama di muka hukum untuk mengakses keadilan. Masalah dasar yang muncul adalah tidak adanya perluasan akses yang sama bagi setiap warga negara untuk mendapatkan perlakuan yang sama di muka hukum, meskipun doktrinnya keadilan harus dapat diakses oleh semua warga negara tanpa terkecuali.

Perlindungan dan pengakuan hak asasi manusia dari setiap individu atau warga negara merupakan suatu kewajiban bagi negara sebagai konsekuensi logis dari penetapannya sebagai negara hokum (Wilujeng, 2013) Indonesia merupakan negara hukum (Pasal 1 ayat (2) UUD 1945) yang memiliki kewajiban untuk melakukan perlindungan dan pengakuan akan hak asasi manusia dari setiap individu atau warga negaranya. Penetapan tersebut diikuti dengan 
pernyataan bahwa setiap warga negara memiliki kedudukan yang sama dihadapan hukum yang dikenal dengan prinsip equality before the law (Diecy, 2007)yang termaktub dalam Pasal 27 ayat (1) UUD 1945.

Konsekuensi dari prinsip equality before the law, seseorang berhak untuk diperlakukan sama dihadapan hukum, termasuk bagi rakyat miskin yang sedang bermasalah dengan hukum. Terlebih lagi, negara Indonesia secara kontitusi pada Pasal 34 ayat (1) UUD 1945 menyatakan bahwa fakir miskin dan anak terlantar diperlihara oleh negara. Frasa "dipelihara" bukan sekedar memberikan kebutuhan akan pangan dan sandang saja, akan tetapi kebutuhan akan akses hukum dan keadilan, dengan kata lain prinsip equality before the law tidak hanya dimaknai sebagai persamaan dimata hukum saja, melainkan menurut Rhode dimaknai sebagai persamaan akan akses terhadap sistem hukum dan keadilan. Berdasarkan hal tersebut terciptalah suatu konsep dan tujuan yang bernama access to law and justice (akses terhadap hukum dan keadilan).

Sebuah data secara berdasarkan keterangan Lembaga Bantuan Hukum (LBH) Bandar Lampung menyatakan, Lembaga Bantuan Hukum (LBH) Bandar Lampung mencatatkan selama tahun 2019 ini, total pemohon bantuan hukum di LBH Bandar Lampung sebanyak 190 pemohon dari berbagai latar belakang dan permasalahan hukum di wilayah Provinsi Lampung. Sebanyak 190 pemohon tersebut, ada sekitar 120 pemohon yang ditangani oleh LBH Bandar Lampung, yang tersebar di 13 kabupaten kota di Provinsi Lampung. Dimana dalam 120 pemohon tersebut, Kota Bandar Lampung mendominasi dengan 76 pemohon.

Data tersebut jumlah pemohon bantuan rata-rata tamatan SLTA dimana ada 61 pemohon. Disusul tamatan diploma 24 orang. Sementara untuk usia pemohon, rata-rata berusia 26 sampai 35 tahun. Dengan jenis kelamin 63 laki-laki dan 57 perempuan. Jumlah pemohon bantuan hukum jika ditarik berdasarkan pekerjaan, maka pekerjaan wiraswasta mendominasi dengan 27 pemohon disusul ibu rumah tangga 24 pemohon. Sementara untuk jumlah kasus struktural ada 23 kasus dan non struktural 97 kasus. Sementara itu, bentuk kasus yang masuk di LBH Bandar Lampung rata-rata kasus individu, dimana terdapat 110 individu. Sedangkan kasus kelompok ada 10 kasus. Layanan bantuan hukum yang dib0erikan LBH Bandar Lampung, bersifat non litigasi yakni 105 bantuan hukum, dan 15 layanan bantuan hukum litigasi.

LBH juga mencatat jumlah kasus berdasarkan permasalahan hukum, terbanyak ada di kasus ketenagakerjaan. Dimana ada 519 penerima manfaat dalam jiwa, dan 11 pemohon bantuan hukum. Untuk kasus pidana, LBH Bandar Lampung mencatat ada 54 pemohon bantuan hukum dengan total penerima manfaat dalam jiwa sebanyak 414 penerima. Kasus perdata, tercatat ada 34 pemohon bantuan hukum dengan total penerima manfaat dalam jiwa ada 405 penerima.

Peraturan perundang-undangan yang mengatur tentang bantuan hukum diantara lain Undang-Undang Nomor 16 Tahun 2011 tentang Bantuan Hukum, Undang-Undang Nomor 16 Tahun 2003 tentang Advokat, Peraturan Pemerintah Nomor 42 Tahun 2013 tentang Syarat dan tata cara pemberian bantuan hukum dan penyaluran dana bantuan hukum (selanjutnya disebut PP Bantuan Hukum), Peraturan Pemerintah Nomor 83 Tahun 2008 tentang Persyaratan dan Tata Cara Pemberian Bantuan Hukum Secara Cuma-cuma. Pengaturan tentang bantuan hukum di 2 undang-undang yang berbeda yaitu Undang-Undang Nomor 16 Tahun 2011 tentang Bantuan Hukum, Undang-Undang Nomor 16 Tahun 2003 tentang Advokat, memberikan asumsi bahwa kedua undang-undang tersebut tumpang tindih. Anggapan adanya benturan antar undang-undang tersebut kemudian menggerakkan beberapa pihak untuk menguji Undang- 
Undang Nomor 16 Tahun 2011 tentang Bantuan Hukum, Undang-Undang Nomor 16 Tahun 2003 tentang Advokat, yang kemudian oleh Mahkamah Konstitusi ditolak permohonannya melalui Putusan Mahkamah Konstitusi Nomor 88/PUU-X/2012 atas uji materiil UndangUndang Nomor 16 Tahun 2011 tentang Bantuan Hukum, Undang-Undang Nomor 16 Tahun 2003 tentang Advokat, terhadap UUD 1945.

UU Bantuan Hukum merupakan sarana negara dalam merepresentatifkan fungsinya sebagai negara hukum, yang mana negara mempunyai wewenang dalam menentukan sarana terhadap aspek-aspek penting pemberian bantuan hukum bagi masyarakat miskin atau kelompok masyarakat tertentu. Aspek tersebut yaitu aspek perumusan aturan hukum, aspek pengawasan terhadap mekanisme pemberian bantuan hukum, dan aspek pendidikan masyarakat agar aturan hukum yang sudah dibuat dapat dihayati.

Semangat yang terkandung dalam UU Bantuan Hukum jelas berbeda dengan pemberian bantuan hukum yang diatur dalam UU Advokat. Pemberian bantuan hukum di UU Advokat merupakan suatu hal yang bersifat melekat (inherent) bagi profesi yang fungsinya melayani kepentingan publik apalagi advokat yang dikenal sebagai officium nobile. Hal tersebut tertuang dalam Putusan Mahkamah Konstitusi Nomor 067/PUU-II/2004.

Negara membentuk aspek penting dalam menjalankan Bantuan Hukum melalui UU Bantuan Hukum berhak menentukan siapa yang bisa memberikan bantuan hukum terhadap kelompok masyarakat miskin agar tercapainya access to law and justice salah satunya profesi advokat. Adanya UU Bantuan Hukum bukanlah menjadi legal insecurity bagi pelaksanaan Bantuan Hukum, karena UU Bantuan Hukum merupakan alat dari negara untuk implementasi bantuan hukum, bukan mencapur adukan istilah pemberian bantuan hukum sebagaimana halnya dalam UU Advokat.

Berdasarkan Undang-Undang Nomor 16 Tahun 2011 tentang Bantuan Hukum yang berhak menerima Bantuan Hukum tertuang dalam Pasal 1 ayat 2 yang menyatakan, "Penerima Bantuan Hukum adalah orang atau kelompok orang miskin”.

Selanjutnya berkaitan dengan ruang lingkup Bantuan Hukun tercantum dalam tertuang dalam Pasal 1 ayat 2 yang menyatakan, "Penerima Bantuan Hukum adalah orang atau kelompok orang miskin".

Pasal 4 Undang-Undang Nomor 16 Tahun 2011 tentang Bantuan Hukum yang menyatakan:

(1) Bantuan Hukum diberikan kepada Penerima Bantuan Hukum yang menghadapi masalah hukum.

(2) Bantuan Hukum sebagaimana dimaksud pada ayat (1) meliputi masalah hukum keperdataan, pidana, dan tata usaha negara baik litigasi maupun nonlitigasi.

(3) Bantuan Hukum sebagaimana dimaksud pada ayat (1) meliputi menjalankan kuasa, mendampingi, mewakili, membela, dan/atau melakukan tindakan hukum lain untuk kepentingan hukum Penerima Bantuan Hukum.

Ruang lingkup Bantuan Hukun juga memuat penerima bantuan hukum dan hak dasar penerima bantuan hukum tercantum dalam Pasal 5 Undang-Undang Nomor 16 Tahun 2011 tentang Bantuan Hukum yang menyatakan: 
(1) Penerima Bantuan Hukum sebagaimana dimaksud dalam Pasal 4 ayat (1) meliputi setiap orang atau kelompok orang miskin yang tidak dapat memenuhi hak dasar secara layak dan mandiri.

(2) Hak dasar sebagaimana dimaksud pada ayat (1) meliputi hak atas pangan, sandang, layanan kesehatan, layanan pendidikan, pekerjaan dan berusaha, dan/atau perumahan.

Access to law and justice merupakan hal yang vital dan mandat terpenting dari United Nations Development Programme untuk mengurangi jumlah kemiskinan dan memperkuat pemerintahan yang demokratis. Access to law and justice bukan sekedar meningkatkan akses ke pengadilan dan menjamin representasi hukum seseorang. Akses terhadap keadilan didefinisikan sebagai kemampuan masyarakat untuk mencari dan memperoleh obat melalui lembaga formal atau informal keadilan bagi keluhan sesuai dengan standar hak asasi manusia.

Hal ini merupakan akses bagi masyarakat, khususnya kelompok miskin terhadap mekanisme yang adil, efektif dan akuntabel untuk melindungi hak, menghindari penyalahgunaan adalah kemampuan masyarakat untuk memperoleh dan mendapatkan penyelesaian melalui mekanisme formal dan informal dalam sistem hukum, serta kemampuan untuk memperoleh dan terlibat dalam proses pembuatan dan penerapan dan pelembagaan hukum.

Akses terhadap keadilan dalam konteks Indonesia mengacu pada keadaan dan proses di mana negara menjamin terpenuhinya hak-hak dasar berdasarkan UUD 1945 dan prinsip-prinsip universal hak asasi manusia, dan menjamin akses bagi setiap warga negara (claim holder) agar dapat memiliki kemampuan untuk mengetahui, memahami, menyadari dan menggunakan hakhak dasar tersebut melalui lembaga-lembaga formal maupun informal, didukung oleh keberadaan mekanisme keluhan publik (public complaint mechanism) yang mudah diakses masyarakat dan responsif, agar dapat memperoleh manfaat yang optimal untuk memperbaiki kualitas kehidupannya sendiri.

Usaha pemerintah mencapai access to law and justice salah satunya dengan mengeluarkan kebijakan affirmative action. Affirmative action ini merupakan merupakan cara yang banyak dipilih oleh negara sebagai jawaban terhadap kondisi sosial yang diskriminatif, adanya ketidaksetaraan dan marginalisasi di segala bidang kehidupan akibat struktur patriarki di level publik dan privat.

Elizabeth S. Anderson, mendefiniskan affirmative action secara luas termasuk semua kebijakan yang mempunyai tujuan. Pertama, mengupayakan penghilangan hambatan dalam sistem dan norma terhadap kelompok sebagai akibat sejarah ketidakadilan dan ketidaksetaraan, dan/ atau, Kedua, mengupayakan promosi masyarakat yang inklusif sebagai prasyarat demokrasi, integrasi, dan pluralisme; Ketiga, mengupayakan kesetaraan atas dasar pengklasifikasian identitas (ras, gender, etnisitas, orientasi seksual, dsb). Salah satu sarana terpenting untuk menerapkan affirmative action adalah hukum dan jaminan pelaksanaannya harus ada konstitusi dan undang-undang (Marzuki, 2009)

\section{Persyaratan dan Mekanisme Pelayanan dan Pendampingan Bantuan Hukum Secara Gratis}

Kehidupan manusia senantiasa memiliki permasalahan, kadang masalah yang menimpa begitu rumit. Hal tersebut dikarenakan manusia adalah makhluk sosial, yang tak lepas dari dinamika sosial yang rawan konflik. Problematika hidup yang besar maupun kecil harus 
senantiasa diselesaikan. Namun untuk menyelesaikan masalah, seringkali tidak bisa dengan mudah untuk di atasi secara mandiri. Sehingga dibutuhkan pihak ketiga untuk membantu menyelesaikan masalah tersebut. Apalagi sampai ke ranah hukum, tentu hal itu membuat kondisi psikologi yang rawan. Ego masing-masing pihak untuk membenarkan pendapatnya membuat perkara semakin menguras pikiran, hati dan bahkan biaya. Maka dari itu orang yang berperkara pidana ataupun perdata membutuhkan nasehat, advis dan bantuan dari orang yang lebih mengetahui tentang hukum acara persidangan.

Sebagai negara hukum (rechtsstaat) sebagaimana bunyi Pasal 1 ayat (3) Undang- Undang Dasar 1945 yang menyatakan "Negara Indonesia adalah negara hukum", maka negara harus menjamin persamaan setiap orang di hadapan hukum serta melindungi hak asasi manusia. Persamaan di hadapan hukum memiliki arti bahwa semua orang memiliki hak untuk diperlakukan sama di hadapan hukum (equality before the law)(Baut, 1990).

Persamaan perlakuan di hadapan hukum bagi setiap orang berlaku dengan tidak membeda-bedakan latar belakangnya (ras, agama, keturunan, pendidikan atau tempat lahirnya), untuk memperoleh keadilan melalui lembaga peradilan. Semua warga negara adalah sama kedudukannya dihadapan hukum, oleh karena itu setiap orang berhak mendapatkan bantuan hukum dalam peradilan yang adil dan tidak memihak. Hak ini merupakan hak dasar setiap manusia. Hak ini bersifat universal, berlaku di manapun, kapan pun dan pada siapapun tanpa ada diskriminasi. Pemenuhan hak ini merupakan tugas dan kewajiban Negara.

Setiap warga Negara tanpa memandang suku, warna kulit, status sosial, kepercayaan dan pandangan politik berhak mendapatkan akses terhadap keadilan.2 Bentuk persamaan perlakuan di hadapan hukum adalah bahwa semua orang berhak untuk memperoleh pembelaan dari advokat sesuai dengan ketentuan undangundang, sehingga tidak hanya orang yang mampu saja yang dapat memperoleh pembelaan dari advokat/penasihat hukum tetapi juga fakir miskin atau orang yang tidak mampu juga dapat hak yang sama dalam rangka memperoleh keadilan (access to justice).

Pada saat itulah Lembaga Bantuan Hukum dibutuhkan masyarakat untuk melayani dan memperjuangkan hak-hak keadilan khususnya bagi masyarakat tidak mampu. Karena kita tahu bahwa biaya yang harus dikeluarkan untuk pengacara professional sangat mahal. Sedangkan masyarakat tidak semuanya mampu untuk membayarnya. Dan mereka sangat terbantu dengan adanya Lembaga Bantuan Hukum yang dapat membantu mereka secara prodeo/gratis.

Layanan bantuan hukum bebas biaya (gratis) melalui pos bantuan hukum (Posbakum) kepada masyarakat luas pencari keadilan. Layanan Posbakum meliputi :

1. Konsultasi Hukum

2. Penyediaan advokat (Penasehat Hukum) Untuk Kasus pidana maupun perdata

3. Pembebasan Biaya perkara untuk kasus pidana maupun perdata

4. Sidang Keliling (Ashshofa, 2007).

Agar memudahkan para pencari keadilan yang memiliki keterbatasan ekonomi untuk mendapatkan bantuan hukum secara gratis melalui advokat yang ditunjuk atau dipercaya oleh pengadilan negeri untuk menangani kasus atau sengketa para pemohon bantuan hukum. Peratuan Pedoman Pos Bantuan Hukum : 
1. Surat Edaran Mahkamah agung RI No. 10 Tahun 2010 Tetang Pedoman Pemberian Bantuan Hukum

2. Keputusan Direktur Jenderal Badan Peradilan Umum No. 1/DJU/OT.01.03/I/2012 tanggal 26 Januari 2012 tentang Petunjuk Pelaksanaan Surat Edaran Mahkamah Agung RI No.10 Tahun 2010 tentang Pedoman Bantuan Hukum Lampiran A Perkara Perdata, Pos Bantuan Hukum dan Zitting Plaats.

Advokat piket di Pos Bantuan Hukum memberikan layanan berupa :

1. Bantuan pengisian formulir permohonan bantuan hukum

2. Bantuan pembuatan dokumen hukum Advis, konsultasi hukum dan bantuan hukum lainnya baik dalam perkara pidana maupun perkara perdata

3. Rujukan kepada Ketua Pengadilan Negeri untuk pembebasan pembayaran biaya perkara sesuai syarat yang berlaku

4. Rujukan kepada Ketua Pengadilan Negeri untuk mendapat bantuan jasa advokat sesuai dengan syarat yang berlaku.

Pemohon Bantuan Hukum harus membuktikan bahwa ia tidak mampu dengan memperlihatkan :

1. Surat Keterangan Tidak Mampu (SKTM) dari Lurah/Kepala desa setempat, atau Surat Keterangan Tunjangan sosial laiinnya, seperti Kartu Keluarga Miskin (KKM),

2. Kartu Jaminan Kesehatan Masyarakat (Jamkesmas), Kartu Program Keluarga Harapan (PKH), Kartu Bantuan Langsung Tunai (BLT); atau

3. Surat pernyataan tidak mampu yang dibuat dan ditandatangani Pemohon Bantuan Hukum dan diketahui oleh Ketua Pengadilan Negeri.

Advokat yang ditunjuk untuk memberikan bantuan dapat :

1. Bertindak sebagai pendamping atau kuasa hukum untuk memberikan bantuan hukum dalam pengurusan sengketa perdata Pemohon bantuan hukum di pengadilan; atau

2. Bertindak sebagai pendamping dan pembela terhadap Pemohon Bantuan Hukum yang didakwa melakukan tindak pidana di pengadilan

Guna memberikan bantuan hukum kepada masyarakat yang tidak mampu, mempunyai Mekanisme atau Alur dalam pemberian bantuan hukum yang harus diikuti atau dipenuhi oleh para pemohon bantuan hukum Berdasarkan SEMA No. 10 Tahun 2010 tentang Pedoman Pemberian Bantuan Hukum sebagai syarat awal agar bisa mendapatkan bantuan hukum secara cuma-cuma/gratis adapun mekanisme pemberian bantuan hukum, yaitu :

1. Untuk memperoleh Bantuan Hukum, Pemohon Bantuan Hukum harus memenuhi syaratsyarat :

a. mengajukan permohonan secara tertulis yang berisi sekurang-kurangnya identitas pemohon dan uraian singkat mengenai pokok persoalan yang dimohonkan Bantuan Hukum;

b. menyerahkan dokumen yang berkenaan dengan perkara; dan

c. melampirkan surat keterangan miskin dari lurah, kepala desa, atau pejabat yang setingkat di tempat tinggal Pemohon Bantuan Hukum.

2. Dalam hal Pemohon Bantuan Hukum tidak mampu menyusun permohonan secara tertulis, permohonan dapat diajukan secara lisan. 
Selanjutnya juga di jelaskan dalam Bab VI Syarat Dan Tata Cara Pemberian Bantuan Hukum Pasal 14 ayat (1) Undang-Undang Nomor 16 Tahun 2011 tentang Bantuan Hukum. Untuk memperoleh Bantuan Hukum, pemohon Bantuan Hukum harus memenuhi syarat-syarat:

a. mengajukan permohonan secara tertulis yang berisi sekurang-kurangnya identitas pemohon dan uraian singkat mengenai pokok persoalan yang dimohonkan Bantuan Hukum;

b. menyerahkan dokumen yang berkenaan dengan perkara; dan c. melampirkan surat keterangan miskin dari lurah, kepala desa, atau pejabat yang setingkat di tempat tinggal pemohon Bantuan Hukum.

Pasal 14 ayat (2) Dalam hal pemohon Bantuan Hukum tidak mampu menyusun permohonan secara tertulis, permohonan dapat diajukan secara lisan.

Pasal 15 :

(1) Pemohon Bantuan Hukum mengajukan permohonan Bantuan Hukum kepada Pemberi Bantuan Hukum.

(2) Pemberi Bantuan Hukum dalam jangka waktu paling lama 3 (tiga) hari kerja setelah permohonan Bantuan Hukum dinyatakan lengkap harus memberikan jawaban menerima atau menolak permohonan Bantuan Hukum.

(3) Dalam hal permohonan Bantuan Hukum diterima, Pemberi Bantuan Hukum memberikan Bantuan Hukum berdasarkan surat kuasa khusus dari Penerima Bantuan Hukum.

(4) Dalam hal permohonan Bantuan Hukum ditolak, Pemberi Bantuan Hukum mencantumkan alasan penolakan.

(5) Ketentuan lebih lanjut mengenai syarat dan tata cara pemberian Bantuan Hukum diatur dengan Peraturan Pemerintah.

Sedangkan penyelenggaran Bantuan Hukum, yaitu :

1. Majelis Hakim menetapkan dan menunjuk Advokat untuk memberikan jasa bantuan hukum dan membuat surat kuasa khusus guna bertindak mewakili, mendampingi, membela dan melakukan tindakan hukum lainnya untuk kepentingan Terdakwa selaku Pemohon Bantuan Hukum.

Penetapan dan penunjukan Advokat diatas wajib di lengkapi dengan :

a. Surat Kuasa Khusus.

b. Surat Keterangan Tidak Mampu dari Lurah atau Kepala Desa setempat atau Kartu Keluarga Miskin (KKM), atau Kartu Jaminan Kesehatan Masyarakat (Jamkesmas), atau Kartu Keluarga Harapan (KKH), atau Kartu Bantuan Langsung Tunai (BLT) atau Surat Pernyataan Tidak Mampu yang dibuat dan ditandatangani Pemohon Bantuan Hukum dan diketahui oleh Ketua Pengadilan Negeri.

2. Berdasarkan Penetapan Penunjukan Advokat untuk memberikan jasa bantuan hukum tersebut, selanjutnya dikeluarkan pula :

a. Penetapan Ketua Pengadilan Negeri yang memerintahkan Kuasa Pengguna Anggaran untuk membayar dana bantuan hukum kepada Advokat yang telah ditunjuk untuk memberikan jasa bantuan hukum kepada Terdakwa.

b. Surat Keputusan Panitera/Sekretaris Pengadilan Negeri selaku Kuasa Pengguna Anggaran membuat Surat Keputusan Pembebanan Dana Bantuan Hukum ke dalam DIPA pengadilan.

3. Pencairan anggaran Bantuan Hukum kepada Advokat dilakukan setelah perkara diputus oleh Pengadilan Negeri dengan melampirkan :

a. Surat Kuasa Khusus 
b. Surat Keterangan Tidak Mampu dari Lurah atau Kepala Desa setempat atau Kartu Keluarga Miskin (KKM), atau Kartu Jaminan Kesehatan Masyarakat (Jamkesmas), atau Kartu Keluarga Harapan (KKH), atau Kartu Bantuan Langsung Tunai (BLT) atau Surat Pernyataan Tidak Mampu yang dibuat dan ditandatangani Pemohon Bantuan Hukum dan diketahui oleh Ketua Pengadilan Negeri.

c. Penetapan Majelis Hakim untuk Penunjukan Advokat yang menjalankan kuasa penerima bantuan hukum.

d. Salinan/Petikan Putusan Perkara tersebut.

Pemberian bantuan hukum oleh lembaga bantuan hukum memiliki peranan yang sangat besar yaitu untuk mendampingi kliennya sehingga dia tidak akan diperlakukan dengan sewenang-wenang oleh aparat, demikian juga untuk membela dalam hal materinya yang mana di sini diharapkan dapat tercapainya keputusan yang mendekati rasa keadilan dari pengadilan. Dengan adanya bantuan hukum secara cuma-cuma atau gratis maka orang yang tidak mampu yang dalam hal ini dimaksudkan pada tingkat perekonomiannya rendah, bisa mendapat keringanan untuk memperoleh penasihat hukum sehingga hak-haknya dapat terlindungi dan proses pemeriksaan perkara tersebut dapat berlangsung sebagaimana mestinya .

\section{KESIMPULAN}

Berdasarkan hasil pembahasan permasalahan di atas maka dapat disimpulkan:

1. Pelayanan bantuan hukum secara cuma-cuma atau gratis dalam Undang-Undang Nomor 16 Tahun 2011 tertuang dalam Pasal 1 ayat 2 dan Pasal ayat 1 sampai dengan ayat 3 Undang-Undang Nomor 16 Tahun 2011 tentang Bantuan Hukum. Ruang lingkup Bantuan Hukun juga memuat penerima bantuan hukum dan hak dasar penerima bantuan hukum tercantum dalam Pasal 5 Undang-Undang Nomor 16 Tahun 2011 tentang Bantuan Hukum tertuang dalam ayat 1 dan ayat 2 .

2. Persyaratan dan mekanisme pelaksanaannya pelayanan bantuan hukum secara cuma-cuma atau gratis dalam Undang-Undang Nomor 16 Tahun 2011 di atur dalam Bab VI Syarat dan Tata Cara Pemberian Bantuan Hukum yang di jelaskan dalam Pasal 14 ayat 1 dan ayat 2, Pasal 15 ayat 1 sampai dengan ayat 5.

\section{DAFTAR PUSTAKA}

A.V. Diecy, 2007 Pengantar Studi Hukum Konstitusi, terjemahan Introduction to the Study of The Law of the Constitution, penerjemah Nurhadi, M.A Nusamedia : Bandung, hlm. 251. Lihat juga didalam Ahmad Ulil Aedi dan FX Adji Samekto, "Rekonstruksi Asas Kesamaan Di Hadapan Hukum (Equality Before The Law), Jurnal Law Reform, Vol. 8 No. 2 Tahun 2013, Program Magister UNDIP : Semarang

Burhan Ashshofa. Metode Penelitian Hukum. Jakarta: Rineka Cipta, 2007.

Deborah L. Rhode, Access to Justice, Oxford University Press : New York, 2004,

Frans Hendra Winatla, Hak Kanstitusional Fakir Miskin Untuk Menperoleh Bantuan Hukun dalam Ranqka Pembangunan Hukum Nasional, Universitates Padjajaran, 2007, 
Seminar Nasional Penelitian dan Pengabdian kepada Masyarakat Universitas Sang Bumi Ruwa Jurai Tahun 2020

lampungpro.co > post > catahu-lbh-bandar-lampung-2020, di Akses 13 Agustus 2020

Mahkamah Konstitusi “Putusan Nomor 88/PUU-II/2012” Pertimbangan hukum

Masnur Marzuki, “Affirmative Action dan Paradoks Demokrasi” Jurnal Konstitusi, PSHK-FH UII, Vol. II, No. 1, Juni 2009, h.

Paul S Baut, Bantuan Hukum di Negara berkembang, Jakarta YLBHI, 1990,

Sri Rahayu Wilujeng, "Hak Asasi Manusia: Tinjauan dari Aspek Historis dan Yuridis", Jurnal Humanika, Vol. 18 No. 2 Edisi Juli-Desember 2013, Fakultas Ilmu Budaya UNDIP: Semarang,

United Nations Development Programme, UNDP, 2005, "Programming for Justice: Access for All: A Practitioner's Guide to a Human Rights-Based Approach to Access to Justice", Thailand, 